\title{
Species Identification and Tree-Ring Dating of the Wooden Elements Used in Juheulgwan of Joryeong (Gate No.1), Mungyeong, Korea ${ }^{1}$ (⿺辶尺)
}

\author{
Kwang Hee $\mathrm{LEE}^{2} \cdot$ Chang Hyun $\mathrm{PARK}^{3} \cdot$ Soo Chul KIM(D)
}

\begin{abstract}
This study's objective was to conduct species identification and tree-ring dating of wooden elements used in Mungyeong Juheulgwan of Joryeong (Gate No. 1). Of the 84 wooden elements evaluated, 76 were confirmed to be hard pines, 5 were soft pines, and 3 belonged to Abies spp. For tree-ring dating, cores of the wooden elements were collected using a drill, and ring-width plots of individual samples were constructed using the TSAP software. The results of performing tree-ring dating for the outermost ring of 59 hard pine wooden elements revealed the following 4 felling dates: summer of $1708^{-}$late fall of 1709 , summer of $1792^{-}$early spring of 1794 , late fall of $1838^{-}$early spring of 1840 and 1867, and early spring-fall of 1872 . These felling dates were found to be consistent with those in the construction and repair records of the Annals of Joseon Dynasty, Juhulgwan Jungsugi, and those engraved on Juhulgwan Walls. It is believed that some of the wooden materials harvested at that time were stored and used since there was a difference of approximately10 years between the repair records and felling dates.
\end{abstract}

Keywords: tree-ring dating, wooden element, hard pine, Juheulgwan, chronology

\section{INTRODUCTION}

Tree growth is determined by the tree's own genetic and environmental factors, and tree rings are formed every year through continuous increase in the thickness and height of trees (Teskey et al., 1987). Among the elements of the tree ring, the tree-ring width is easy to measure and stores various environmental information; therefore, it is commonly used in tree-ring dating (Seo et al., 2017). Tree-ring dating is a method used to measure the age of trees using the width of the tree rings, and to use this method, it is necessary to establish a standard tree-ring chronology for each region and species (Lee et al., 2018). Pine, a major tree species in Korea's forests, was the most preferred building material in Korea (Park and Lee, 2007), and since the establishment of a standard tree-ring pattern for pine trees at the end of the Goryeo period, tree-ring

\footnotetext{
${ }^{1}$ Date Received August 24, 2021, Date Accepted October 12, 2021

${ }^{2}$ Research Institute of Wooden Cultural Heritage, Korea National University of Cultural Heritage, Republic of Korea

${ }^{3}$ Department of Heritage Conservation and Restoration, Graduate School of Cultural Heritage, Korea National University of Cultural Heritage, Republic of Korea

${ }^{4}$ Department of Conservation Science, Korea National University of Cultural Heritage, Republic of Korea

$\dagger$ Corresponding author: Soo Chul KIM (e-mail: kim6768@hanmail.net, ORCID: 0000-0002-3508-8386)
} 
dating of many wooden structures are being conducted (Lee et al., 2021).

Tree-ring dating has been used for the domestic wooden structures in many buildings, first of which was the Gyeonghoeru Pavilion in Gyeongbokgung Palace. Among them, a study confirmed the mutual relationship between the 55 wooden elements of Daeungjeon in the Yeongguk Temple in Yeongdong and the carbonized building elements excavated from the lower part of Daeungjeon using absolute dating (Son et al., 2006). Another study conducted species identification and tree-ring dating of the wooden elements in Daeseongjeon of Jipyeonghyangyo in Yangpyeong and identified 43 hard pine and 6 soft pine trees and confirmed their felling dates to be 1718 and 1720 , which enabled the confirmation of the repair period by comparing them with the historical records (Son et al., 2011). Additionally, by tree-ring dating of the wooden elements and heartwood materials of the main, wing, and entrance parts of the Gwanghanru Pavilion in Namwon, the felling dates of the wooden elements of the primary and wing parts were discovered to be similar, which enabled the comparison and confirmation of the period of construction, renovation, and extension of the entrance part with historical records (Park et al., 2014). Species identification and tree-ring dating was performed for the wooden elements of Daeunjeon of the Hwagyesa Temple in Seoul, and the presence of 26 hard pines and 1 tree of the Abies spp. were confirmed. After performing tree-ring dating, the felling dates of the wooden elements were found to be 1869 and 1870, which were confirmed to be consistent with those in the construction and hidden material records (Bokjangmul) in Jongdori (Lee et al., 2020). Since such wooden buildings are made of biological materials, they are vulnerable to decay and deterioration, and with time, they will be exposed to damage by wind and insects (Eom and Park, 2018). Therefore, to maintain a wooden structure for a long time, repairs and replacements of elements are carried out. Accordingly, it is important to understand the construction, repair, and replacement periods of the structures.

Mungyeong Juheulgwan of Joryeong (Gate No.1) is the historic site no. 147, and the fortress has a gatehouse with a 3-block wide and 2-block long hipped and gabled roof and two side doors (Fig. 1). Among the three gates of Mungyeong Saejae, the first gate (Juhulgwan) has the oldest appearance and is said to have been built in 1709 (35th year of King Sukjong). It was recorded in "Juheulgwan Jungsugi" that after its construction, repairs were carried out in 1752 (28th year of King Yeongjo), 1772 (48th year of King Yeongjo), and 1840 (6th year of King Hyeonjong); additionally, it was engraved on Juheulgwan Walls that it was reconstructed and extended in 1721 (1st year of King Gyeongjong), 1748 (24th year of King Yeongjo), 1808 (8th year of King Sunjo), 1880 (17th year of King Gojong), and 1886 (23rd year of King Gojong) (Mungyeong city, 2020). However, these records only recorded the time of reconstruction and repair of Juheulgwan, and it was impossible to confirm the type of wood used, their date of felling, date of use, etc.

Therefore, in this study, tree-ring dating was performed for the wooden elements in the gatehouse and side doors of Mungyeong Juheulgwan of Joryeong

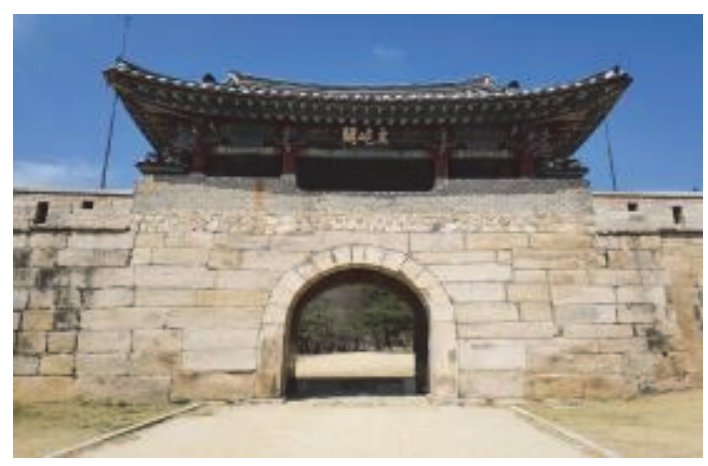

Fig. 1. Juheulgwan of Joryeong (Gate No.1), Mungyeong, Korea. 
(Gate No.1) to determine the time of reconstruction and repair. In addition, species identification was conducted for the same wooden materials to validate the tree species used.

\section{MATERIALS and METHODS}

\subsection{Target of analysis}

Core samples from the area close to the tree skin were obtained from 84 wooden elements (containing $\geq 50$ tree rings) of the gatehouse and side doors of Juheulgwan (Tables 1 and 2). The samples were obtained via a coring method in which a specially prepared core-type bit was combined with an electric drill to obtain a core (within a diameter of $6 \mathrm{~mm}$ and a length of $8 \mathrm{~cm}$ ). After obtaining the sample, the punctured part was treated using an antiseptic (Wood keeper-A, Hanchem, Korea) and was filled with resin for the maintenance of the cultural properties of the wooden materials (Resin-SV 427, hardener-HV 427). The coring method has been applied to several buildings since the early 2000 s. It never leads to problems such as deterioration or deformation of the wooden elements because it uses resin for the maintenance of the cultural properties of the elements, which can be restored after sample collection.

\subsection{Analysis method}

\subsubsection{Species identification}

From the cores obtained for tree-ring dating, three-section slices with a thickness of approximately $20 \mu \mathrm{m}$ were prepared by hand sectioning using a razor blade. The three sections were placed on a glass slide, $50 \%$ of aqueous glycerin solution was added, and a preparat for species identification was prepared while taking care that bubbles are not formed. An optical microscope (Eclipse LV100, Nikon, Japan) was used to observe the tissues in the prepared sections, and pictures were taken of the features that were found to enable identification of the tree species.

\subsubsection{Tree-Ring dating}

The collected cores were attached to a fixed stand and sanded using sandpaper such that the tree rings

Table 1. The numbers of samples for analysis of gatehouse

\begin{tabular}{|c|c|c|c|c|c|}
\hline \multicolumn{2}{|c|}{ Sample } & \multirow{2}{*}{$\begin{array}{c}\text { Number } \\
8\end{array}$} & \multicolumn{2}{|c|}{ Sample } & \multirow{2}{*}{$\begin{array}{c}\text { Number } \\
4\end{array}$} \\
\hline Dil & Gidung & & Bracket arm & Ikgong & \\
\hline Pillar & Dong ja ju & 2 & Angle rafter & Chunyeo & 3 \\
\hline \multirow{3}{*}{ Beam } & Daebo & 2 & End angle rafter & Sarae & 3 \\
\hline & Chungbo & 2 & Truss & Dae gong & 2 \\
\hline & Jongbo & 2 & Floor frame & Jangsun & 14 \\
\hline Head-penetrating tie & Changbang & 4 & Roof panel & Hab gag nul & 2 \\
\hline Purlin & Dori & 5 & $\mathrm{Nu}$ ri gae & & 2 \\
\hline Jangyeo & - & 3 & Rafter & & 14 \\
\hline Capital & Judu & 2 & Other materials & & 5 \\
\hline
\end{tabular}

Table 2. The numbers of samples for analysis of side door

\begin{tabular}{cccc|ccc}
\hline & Sample & & Number & Sample & Number \\
\hline \hline Pillar & & Gidung & 3 & Purlin & Dori & 2 \\
\hline
\end{tabular}


Species Identification and Tree-Ring Dating of Wooden Elements in Juheulgwan of Joryeong (Gate No.1), Mungyeong, Korea

could be clearly observed. The tree rings of each sample were measured with an accuracy of $0.01 \mathrm{~mm}$ using a stereomicroscope (LEICA-S4E, Leica, Germany) and a tree-ring width measurement equipment (LINTAB Germany) connected to the TSAP-Win software (Rinntech, Germany). Cross-dating was conducted to identify the false and true rings of the measured samples and assign the exact age to each tree ring (Kim and Park, 2005; Speer, 2010; Soltani et al., 2021). The representative cross-dating methods utilized in tree-ring dating involve a statistical method that calculates the mutual conformity in the tree-ring dates and a graphic method in which the conformity in tree-ring chronology is visually confirmed (Schweingruber, 1988; Norrgard and Helama, 2021). The statistical method can be considered significant at the $1 \%$ level when the t-value is $\geq 3.5$, and the Gleichläufigkeit (glk) value is $\geq 65 \%$ or more when the tree-ring width graphs for $\geq 100$ years are compared (Park et al., 2003). Therefore, for tree-ring dating, both graphical and statistical analyses were conducted. To assign an absolute year to the written Mungyeong Joryeong Juheulgwan chronology, cross-dating was conducted using the standard chronology of hard pine owned by the Korea National University of Cultural Heritage.

\section{RESULTS and DISCUSSION}

\subsection{Species identification}

The species identification results of the 84 wooden elements ( 79 from the gatehouse and 5 from the side doors of Mungyeong Juheulgwan of Joryeong) showed that 76 of them were hard pines, 5 were soft pines, and 3 were Abbies spp. Tables 3 and 4 summarize

Table 3. The result of species identification for gatehouse

\begin{tabular}{|c|c|c|c|c|c|}
\hline \multicolumn{2}{|c|}{ Sample } & \multirow{2}{*}{$\frac{\text { Species }}{\text { Hard pine }}$} & \multicolumn{2}{|c|}{ Sample } & \multirow{2}{*}{$\frac{\text { Species }}{\text { Hard pine }}$} \\
\hline \multirow{10}{*}{ Pillar } & Inside Gidung 1 & & \multirow{2}{*}{ Truss } & Dae gong 1 & \\
\hline & Inside Gidung 2 & Hard pine & & Dae gong 2 & Hard pine \\
\hline & Inside Gidung 3 & Hard pine & \multirow{14}{*}{ Floor frame } & Door Jangsun 1 & Hard pine \\
\hline & Inside Gidung 4 & Soft pine & & Door Jangsun 2 & Hard pine \\
\hline & Inside Gidung 5 & Hard pine & & Jangsun 1 & Hard pine \\
\hline & Outside Gidung 1 & Hard pine & & Jangsun 2 & Hard pine \\
\hline & Outside Gidung 2 & Hard pine & & Floor Jangsun 1 & Hard pine \\
\hline & Outside Gidung 3 & Hard pine & & Floor Jangsun 2 & Hard pine \\
\hline & Dong ja ju 1 & Hard pine & & Floor Jangsun 3 & Abies spp. \\
\hline & Dong ja ju 2 & Hard pine & & Floor Jangsun 4 & Hard pine \\
\hline \multirow{6}{*}{ Beam } & Daebo 1 & Hard pine & & Floor Jangsun 5 & Hard pine \\
\hline & Daebo 2 & Hard pine & & Floor Jangsun 6 & Hard pine \\
\hline & Chungbo 1 & Hard pine & & Floor Jangsun 7 & Hard pine \\
\hline & Chungbo 2 & Hard pine & & Floor Jangsun 8 & Abies spp. \\
\hline & Jongbo 1 & Hard pine & & Floor Jangsun 9 & Hard pine \\
\hline & Jongbo 2 & Hard pine & & Floor Jangsun 10 & Abies spp. \\
\hline \multirow{4}{*}{$\begin{array}{c}\text { Head } \\
\text { penetrat-ing } \\
\text { tie }\end{array}$} & Changbang 1 & Hard pine & \multirow{2}{*}{ Roof panel } & Hab gag nul 1 & Hard pine \\
\hline & Changbang 2 & Hard pine & & Hab gag nul 2 & Hard pine \\
\hline & Changbang 3 & Hard pine & \multirow{2}{*}{$\mathrm{Nu}$ ri gae } & $\mathrm{Nu}$ ri gae 1 & Hard pine \\
\hline & Changbang 4 & Hard pine & & $\mathrm{Nu}$ ri gae 2 & Hard pine \\
\hline
\end{tabular}


Table 3. Continue

\begin{tabular}{|c|c|c|c|c|c|}
\hline \multicolumn{2}{|c|}{ Sample } & \multirow{2}{*}{ 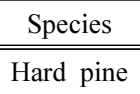 } & \multicolumn{2}{|c|}{ Sample } & \multirow{2}{*}{$\frac{\text { Species }}{\text { Hard pine }}$} \\
\hline \multirow{5}{*}{ Dori } & Dori 1 & & \multirow{14}{*}{ Rafter } & Sun ja yeon 1 & \\
\hline & Dori 2 & Hard pine & & Sun ja yeon 2 & Hard pine \\
\hline & Dori 3 & Hard pine & & Sun ja yeon 3 & Hard pine \\
\hline & Dori 4 & Hard pine & & Sun ja yeon 4 & Hard pine \\
\hline & Dori 5 & Hard pine & & Jang yeon 1 & Hard pine \\
\hline \multirow{3}{*}{$\begin{array}{c}\text { Jang } \\
\text { yeo }\end{array}$} & Jangyeo 1 & Hard pine & & Jang yeon 2 & Hard pine \\
\hline & Jangyeo 2 & Hard pine & & Jang yeon 3 & Hard pine \\
\hline & Jangyeo 3 & Hard pine & & Jang yeon 4 & Hard pine \\
\hline \multirow{2}{*}{ Capital } & Judu 1 & Hard pine & & Sang yeon 1 & Hard pine \\
\hline & Judu 2 & Hard pine & & Sang yeon 2 & Hard pine \\
\hline \multirow{4}{*}{ Bracket arm } & Ikgong 1 & Hard pine & & Sang yeon 3 & Hard pine \\
\hline & Ikgong 2 & Hard pine & & Sang yeon 4 & Hard pine \\
\hline & Ikgong 3 & Hard pine & & Bu yeon 1 & Hard pine \\
\hline & Ikgong 4 & Hard pine & & Bu yeon 2 & Soft pine \\
\hline \multirow{3}{*}{$\begin{array}{l}\text { Angle } \\
\text { rafter }\end{array}$} & Chunyeo 1 & Soft pine & \multirow{5}{*}{ Other elements } & Roof material 1 & Hard pine \\
\hline & Chunyeo 2 & Hard pine & & Roof material 2 & Hard pine \\
\hline & Chunyeo 3 & Hard pine & & Roof material 3 & Hard pine \\
\hline \multirow{3}{*}{$\begin{array}{l}\text { End } \\
\text { angle } \\
\text { rafter }\end{array}$} & Sarae 1 & Hard pine & & Floor materal 1 & Hard pine \\
\hline & Sarae 2 & Hard pine & & Floor materal 2 & Hard pine \\
\hline & Sarae 3 & Hard pine & \multicolumn{2}{|c|}{ Total } & 79 \\
\hline
\end{tabular}

Table 4. The result of species identification for side door

\begin{tabular}{c|c|c||c|c|c}
\hline \multicolumn{2}{c|}{ Sample } & Species & \multicolumn{2}{|c|}{ Sample } & Species \\
\hline \hline \multirow{3}{*}{ Pillar } & Gidung 1 & Soft pine & \multirow{2}{*}{ Purlin } & Dori 1 & Hard pine \\
\cline { 2 - 4 } & Gidung 2 & Hard pine & & Dori 2 & Hard pine \\
\cline { 2 - 5 } & Gidung 3 & Soft pine & & \multicolumn{2}{|c|}{ Total } \\
\hline
\end{tabular}

the species identification results according to the type of wooden element.

\subsubsection{Description of anatomical features according to subspecies}

1) Hard pine: PINACEAE, Pinus spp.

This softwood undergoes a rapid transition from earlywood to latewood. Vertical vessels with thin-walled epithelial cells were observed under optical microscope. The ray cells were composed of ray parenchyma and ray tracheid, and one window-like pit was observed in the cross-field. Particularly, dentate thickening, which is the main feature of hard pines belonging to the Pinus spp., was observed in the ray tracheid. In the longitudinal ray tracheid, an arrangement of bordered pits was observed in one row. In the tangential section, horizontal vessels were observed, and uniseriate and fusiform ray cells were also observed (Fig. 2). Within the Pinus spp., hard pines and soft pines exist, and the sample was finally identified as hard pine since 

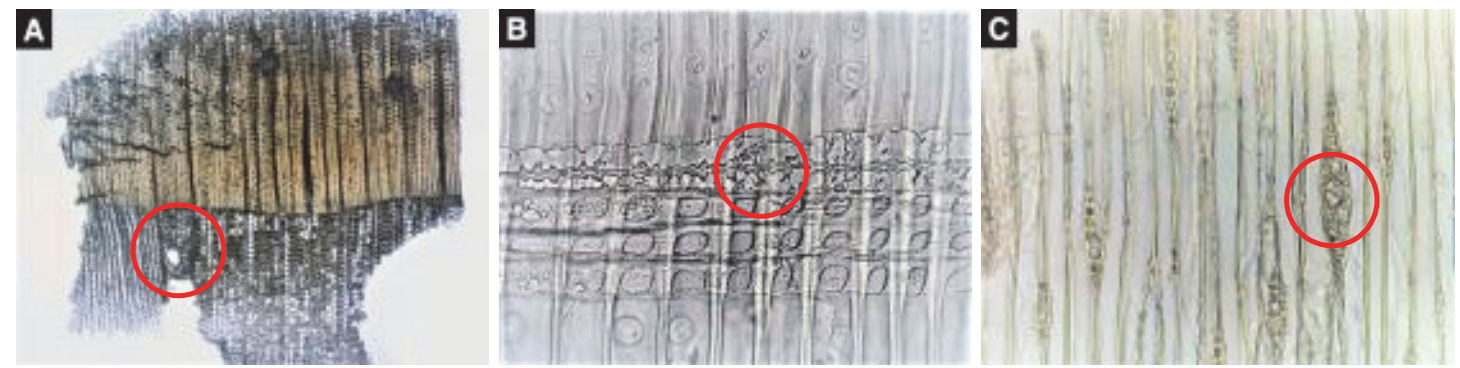

Fig. 2. Micrographs of Hard pine species $(A=$ Cross section $(\times 40), B=$ Radial section $(\times 400)$, $C=$ Tangential section $(\times 200))$.
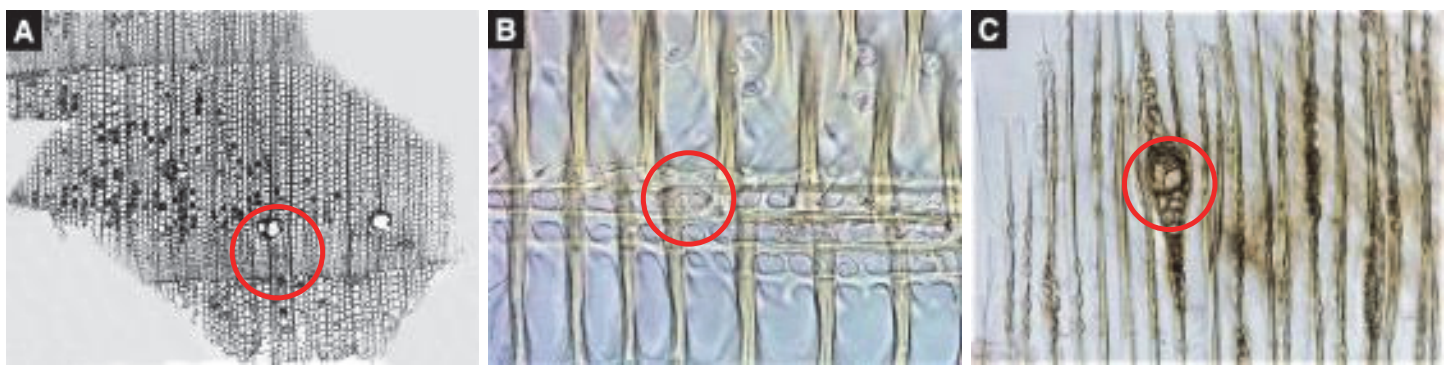

Fig. 3. Micrographs of Soft pine species $(A=C$ ross section $(\times 40), B=$ Radial section $(\times 400)$, $C=$ Tangential section $(\times 200))$.

dentate thickening was observed.

2) Soft pine: PINACEAE, Pinus spp.

This is a hardwood that undergoes a slow or slightly rapid transition from earlywood to latewood. When viewed under optical microscope, vertical vessels with thin-walled epithelial cells were observed. The ray cells consisted of ray parenchyma and ray tracheid, and two window-like pits of one were mainly seen in the observation field. Unlike the hard pines that belong to the Pinus spp., dentate thickening was not observed in the ray tracheid. A one-row arrangement of bordered pits was observed in the longitudinal ray tracheid. In the tangential section, horizontal vessels were observed. Additionally, both uniseriate and fusiform ray cells were observed (Fig. 3). The Pinus spp. consist of both hard and soft pines; however, since dentate thickening was not observed, the sample was finally identified to be soft pine.

\section{3) Abies spp.: PINACEAE}

This is a softwood that undergoes a gradual transition of tracheids from earlywood to latewood. No normal resin canals were observed in the prepared cross-section. The ray cells comprised only of ray parenchyma, and the horizontal wall of the ray parenchyma had well-developed simple pit pairs and modular end walls. In the cross-field, 2-3 taxodioid pits were observed. The bordered pits in the longitudinal ray tracheid were arranged in one or two rows. No horizontal vessels were observed in the tangential section, and only uniseriate rays were observed (Fig. 4). The Abies spp. distributed in Korea consists of three species, namely, A. holophylla, A. nephrolepis, and A. koreana; however, since they are anatomically indistinguishable, the sample was finally identified as Abies spp. 

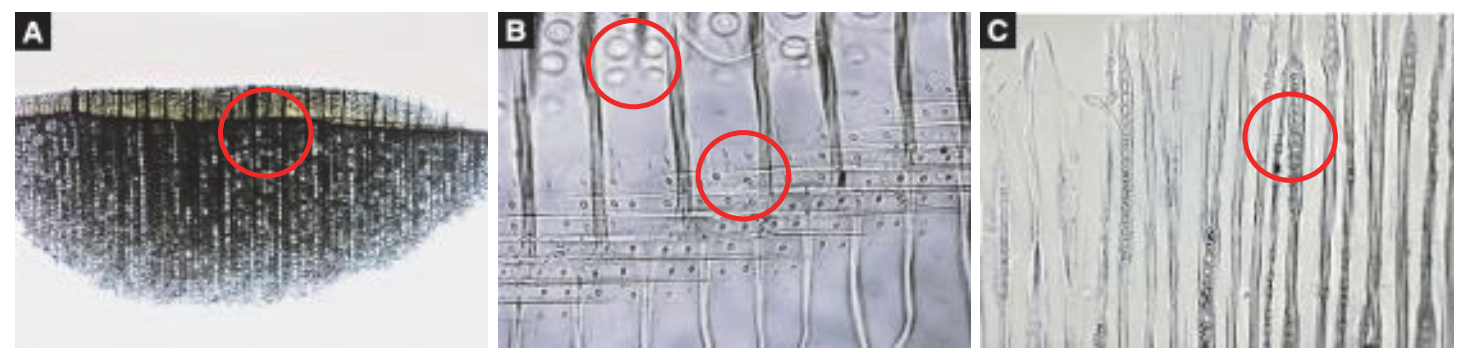

Fig. 4. Micrographs of Abies spp. species $(A=$ Cross section $(\times 40), B=$ Radial section $(\times 400), C=$ Tangential section $(\times 200)$ ).

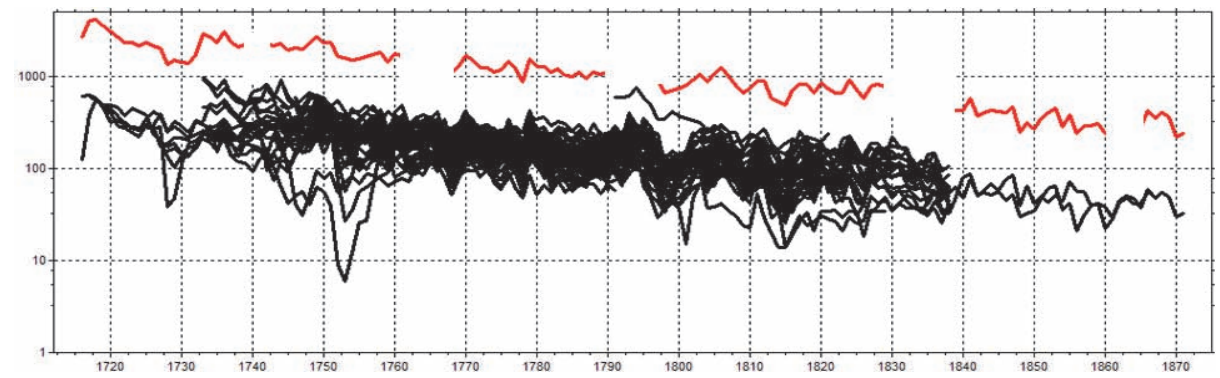

Fig. 5. The Joryeong chronology (JRPD 1S) made from wood elements of Juheulgwan (red graph: the Joryeong chronology, under graph: chronology of 54 wood elements).

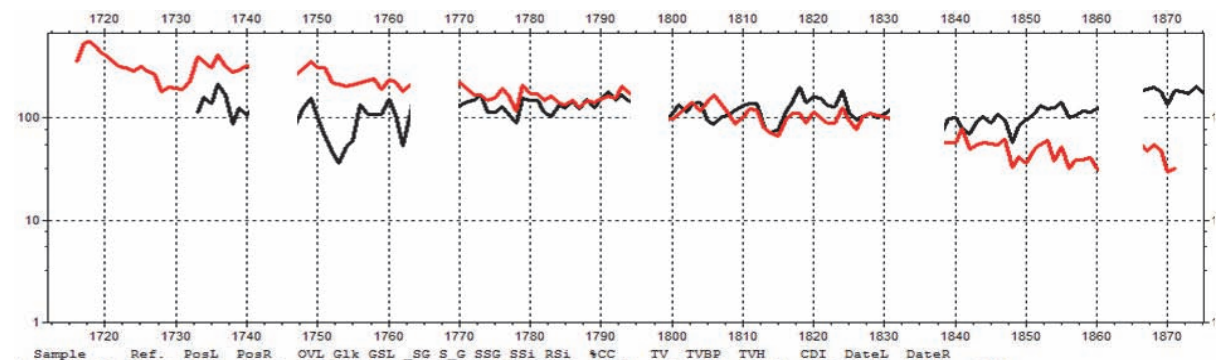

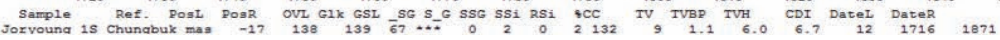

Fig. 6. The Joryeong chronology (JRPD 1S) cross-dated with master-chronology (red graph: JRPD 1S, black graph: master-chronology).

\subsection{Tree-Ring dating}

Among the 84 samples obtained from the gatehouse and side doors of Mungyeong Juheulgwan of Joryeong, 76 samples of hard pine, excluding the 5 samples identified as soft pine and 3 samples identified as Abies spp., were included for further analysis. Among the 76 samples, 54 were similar to each other, creating Chronology 1 (Joryeong 1S; Fig. 5). The tree-ring pe- riod was 157 years, and to find out the exact year, cross-dating was conducted using the standard chronology of hard pine owned by the Korea National University of Cultural Heritage. On analysis, the t-value was found to be 6.7, and the G-value was $67 \%$, which was a relatively high statistical value and graphically consistent (Fig. 6). Therefore, Mungyeong Juheulgwan of Joryeong (Gate No.1) hard pine Chronology 1 (Mungyeong 1S) was dated as 1744-1869. Among the 


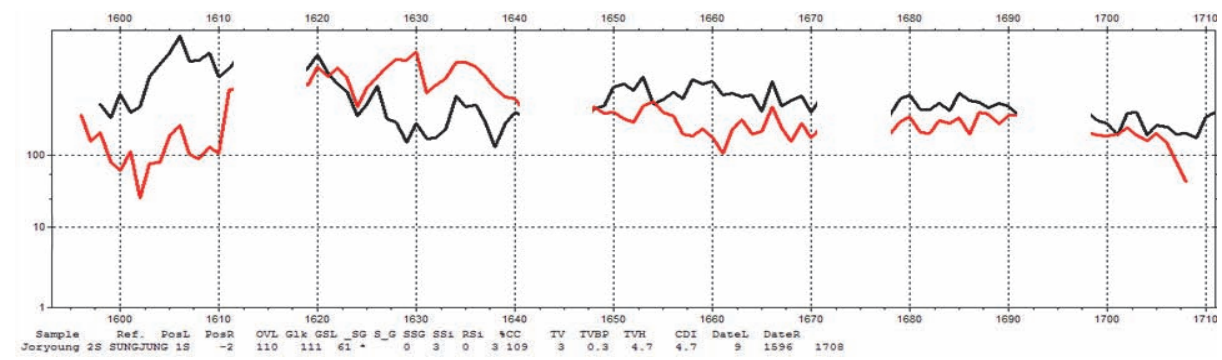

Fig. 7. The Joryeong chronology (JRPD 2S) cross-dated with master-chronology (red graph: JRPD 2S, black graph: master-chronology).

wooden elements included in the chronicle, it was validated that wood harvested from the summer of 1792 to the early spring of 1794 was used for some pillars, groves, and sangyeons with bark, and most of the elements were made from wood harvested from the late autumn of 1838 to the early spring of 1840 . Additionally, it was confirmed that the timber for the unknown floor element 1 and the unknown roof element 3 were felled between the early spring and autumn of 1867 and 1872, respectively. Furthermore, the floor joists and five joists were similar to each other, thereby creating Chronology 2 (Joryeong 2S). The tree-ring period was found to be 113 years, and on performing cross-dating using the hard pine standard chronology, the statistical values of t-value (4.7) and G-value (61\%) were found to be graphically consistent. Therefore, Mungyeong Joryeong Gwanmun Gate 1 (Juheulgwan) hard pine Chronology 2 (Joryeong 2S) was dated as 1596-1709 (Fig. 7). Two of the elements involved in the chronicle (floor joists 2 and joists 2) had bark; therefore, it was confirmed that they were felled between the summer of 1708 and late autumn of 1709 .

\subsection{Study}

On conducting species identification of the 84 wooden elements of Mungyeong Juheulgwan of Joryeong (Gate No.1), 76, 5, and 3 wooden elements were identified to be hard pine, soft pine, and Abies spp., respectively. Pine trees of the hard pine type are species that grow wild in all regions of Korea, except for the northern highlands of the Korean Peninsula, and were found to be mainly used in wooden structures in the Joseon Dynasty as per previous studies (Park and Lee, 2007). The same results were validated in this study. There are three types of soft pines native to KoreaKorean pine, Ulleungdo white pine, and Dwarf stone pine. The Ulleungdo white pine is native to Ulleungdo, and the Dwarf stone pine is native to the northern part of the Korean Peninsula in which Seoraksan Mountain is the timberline; therefore, it is unlikely that the Ulleungdo white and Dwarf stone pines were used and highly likely that the Korean pine was used (Kong, 2000). Additionally, although A. holophylla, A. nephrolepis, and $A$. koreana belong to the Abies spp., A. nephrolepis and A. koreana are mainly distributed in highland areas; therefore, it is believed that $\mathrm{A}$. holophylla was used (Lee, 1997). Furthermore, soft pine and Abies spp. are unsuitable for use as building materials because they are less sturdy than hard pine. Therefore, it was considered that Mungyeong Joryeong Juheulgwan was built mainly using hard pine; however, if the supply of hard pine was insufficient, soft pine and Abies spp. were used. This is consistent with the results that stated that hard pine was primarily used in the palace and administrative buildings during the Joseon Dynasty, but some soft pine and Abies spp. were also used (Park and Lee, 2007).

Because of tree-ring dating, dates were assigned to 
59 of the 76 hard pines analyzed, and 4 felling dates were identified. It was confirmed that the joist members of the floor were felled between the summer of 1708 and late autumn of 1709 , and thus were considered to be early construction members. Most of the other members were felled throughout one and a half years, from late autumn of 1838 to early spring of 1840 , and it is believed that large-scale repairs were carried out 130 years after the construction. Additionally, it is believed that some of the outer columns, nurigae, and sangyeon were felled between the summer of 1792 and the early spring of 1794 , showing that repairs and replacements of some members were carried out 150 years after the large-scale repair. Afterward, it was confirmed that a floor member, presumed to be a dongbari, and one unidentified roof member each were felled in 1867 and 1872, suggesting that after 1872, a simple repair was carried out on the floor to replace some decomposed parts with dongbari, in addition to carrying out repairs on the roof (Fig. 8).

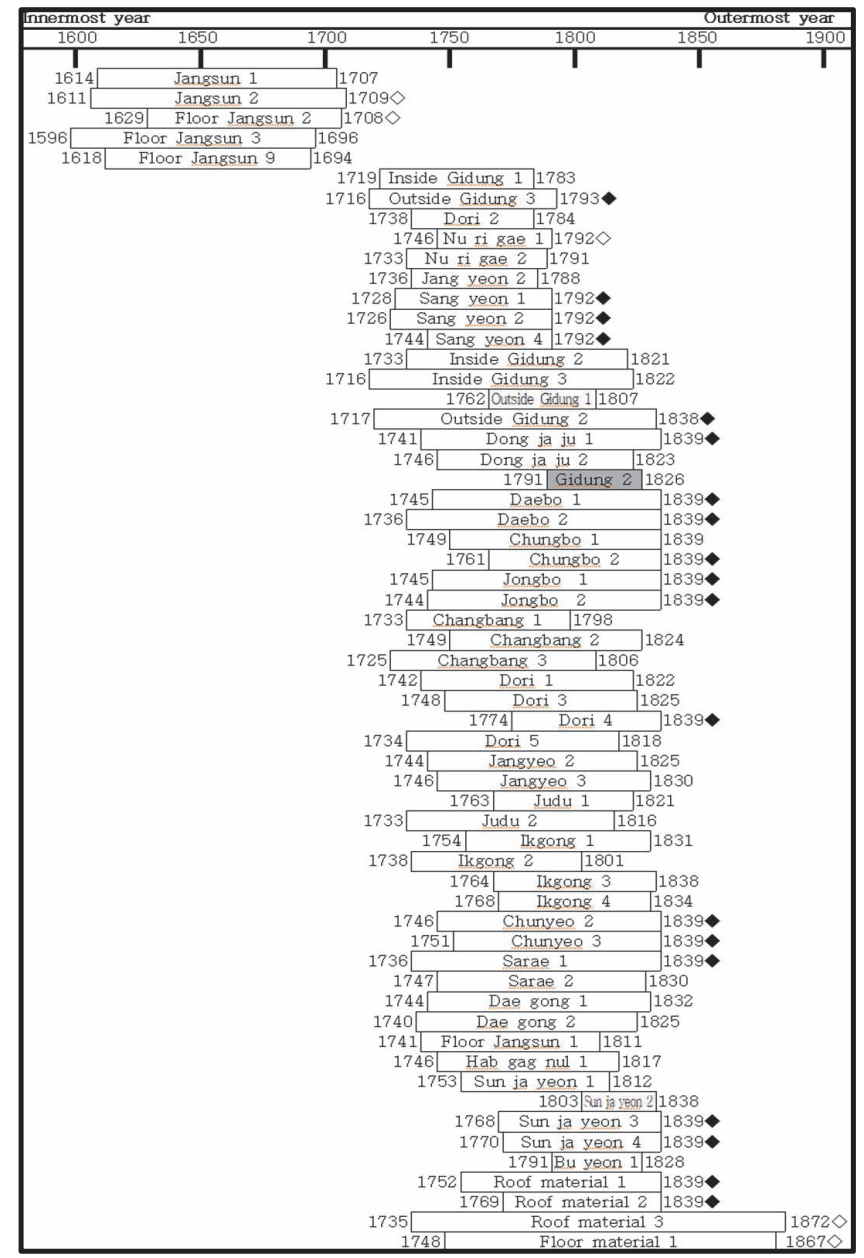

Fig. 8. Dendrochronological dates of individual wood elements included in Joryeong chronologies $(\bullet$ indicated the outermost annual rings that are just below barks and have completed latewood formation; $\diamond$ indicated the outermost annual rings that form earlywood;

$\square$ : Side door material). 


\section{CONCLUSION}

Mungyeong Joryeong Juheulgwan selectively used hard pine as building materials for the gatehouse and side doors. It was confirmed that soft pine and Abies spp. were used for some missing members; this result was consistent with that of a previous report on the tree species used in the palace and official buildings of the Joseon Dynasty (Part et al., 2018). Additionally, the chronology prepared by tree-ring dating correlated the highest statistical value with the Chungcheong-do standard chronology of hard pine from Worak Mountain and Songni Mountain, suggesting that the hard pine that was naturally grown near Mungyeong was supplied for use in repairs and replacements.

The tree-ring dating identified 4 felling dates for the 58 wooden elements of the gatehouse and 1 wooden element of the side door. The confirmed felling dates were compared with the construction and repair records of Joryeong Juheulgwan in Mungyeong (Annals of Joseon Dynasty, Juheulgwan Jungsugi, and engravements on Juheulgwan Walls; Table 5). Among the records of Joryeong Juheulgwan in Mungyeong, "Annals of Joseon Dynasty-Sukjong" and "Yeojidoseo" contained the records where the construction of
Joryeong was discussed in the 34th year of Sukjong (1708), and it was stated that construction started from the spring of the following year, the 35th year of Sukjong (1709) (Mungyeong city, 2020). Many joists, which were floor members, were confirmed to have similar dates through tree-ring dating, suggesting that they were the early construction members. In "Juheulgwan Jungsugi," there is a record that state that repairs were carried out in the 6th year of King Heonjong (1840), and as most of the members were confirmed to be felled between 1838 and 1840, it was judged that reconstruction or large-scale repairs were carried out in 1840 (Mungyeong city, 2020). Additionally, there was a record engraved in the Juheulgwan Walls that stated that repairs were carried out in 1808. Using tree-ring dating, it was confirmed that columns and dori were felled between 1792 and 1794, suggesting that relatively heavy repairs were carried out in 1808 using the timber they felled 10 years ago. Furthermore, according to the records on the fortress walls that stated that repairs carried out in 1880 and 1886, it was believed that were used for simple repairs to the floor and roof using woods, which were felled in 1867 and 1872, respectively.

Different repair records of Mungyeong Joryeong

Table 5. The comparison with repair records and tree-ring dating results

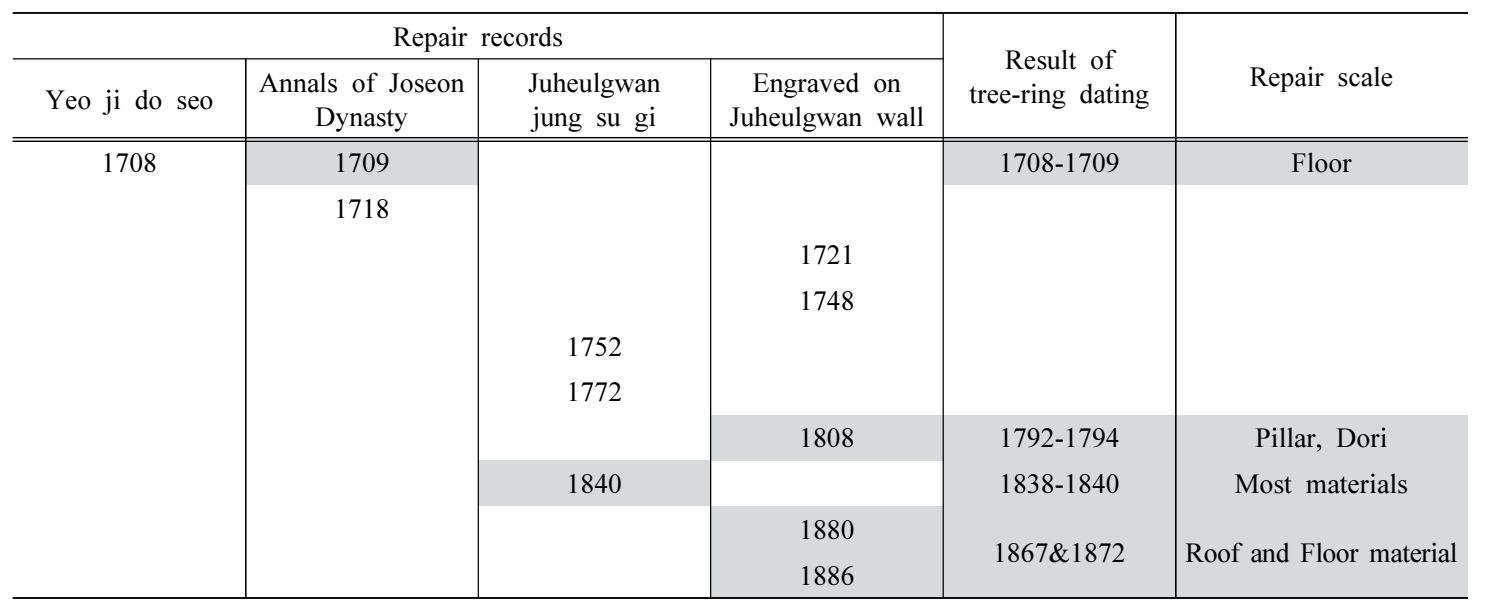


Juheulgwan were confirmed through the books and engravings on the fortress walls. These were consistent with the results of tree-ring dating obtained in our study, which once again confirmed the accuracy of tree-ring dating. Additionally, because there was a difference of approximately 10 years between the repair records and felling dates of some elements of the building, it was assumed that the timber was felled and stored at that time. We believe that it will be possible to gain more precise information regarding the storage methods and usage of the wood used in buildings during the Joseon Dynasty once tree-ring dating is continuously conducted for other Joseon Dynasty buildings as well.

\section{REFERENCES}

Eom, Y.J., Park, B.D. 2018. Wood Species Identification of Documentary Woodblocks of Songok Clan of the Milseong Park, Gyeongju, Korea. Journal of the Korean Wood Science and Technology 46(3): 270-277.

Kim, Y.J., Park, W.K. 2005. Tree-ring dating of Korean woodcraft of the late Joseon and the Modern era: A case study. Korean Journal of Art History 246(8): 247-274.

Koog, W.S. 2000. Geoecology on the Subalpine Vegetation and Landscape of Mt. Sorak. Journal of the Korean Geographical Society 35(2): 177-187.

Lee, K.H., Lee, U.C., Kang, P.W., Kim, S.C. 2021. Analysis and Tree-Ring Dating of Wooden Coffins Excavated from Incheon Sipjeong-Dong Site. Journal of the Korean Wood Science and Technology 49(1): 67-81.

Lee, K.H., Park, C.H., Kim, S.C. 2020. Species Identification and Tree-Ring Analysis of Wooden Elements in Daewoong-jeon of Hwagye-temple, Seoul, Korea. Journal of conservation science 36(5): 326-332.
Lee, K.H., Seo, J.W., Han, G.S. 2018. Dating Wooden Artifacts Excavated at Imdang-dong Site, Gyeongsan, Korea and Interpreting the Paleoenvironment according to the Wood Identification. Journal of the Korean Wood Science and Technology 46(3): 241-252.

Lee, P.W. 1997. Properties and Uses of Korean wood ( I ). Seoul National University Press, Seoul, Korea. Mungyeong city, 2020. Mungyeong Joryeong (Gate No.1): Dismantling Precision Survey Report. Mungyeong city, Gyeongsangbuk-do, Korea.

Norrgård, S., Helama, S. 2021. Dendroclimatic investigations and cross-dating in the 1700s: The tree-ring investigations of Johan Leche (1704-1764) in southwestern Finland. Canadian Journal of Forest Research 51(2): 267-273.

Park, J.H., Oh, J.E., Hwang, I.S., Jang, H.U., Choi, J.W., Kim, S.C. 2018. Study on Species Identification for Pungnammun Gate (Treasure 308) in Jeonju, Korea. Journal of the Korean Wood Science and Technology 46(3): 278-284.

Park, W.K., Kim, Y.J., Han, S.H. 2014. Dendrochronological Dating for the Gwanghanru Pavilion, Namwon, Korea. Annual Review in Cultural Heritage Studies 47(1): 152-163.

Park, W.K., Lee, K.H. 2007. Changes in the Species of Woods used for Korean Ancient and Historic Architectures. Journal of Architectural History 16(1): 9-28.

Park, W.K., Son, B.H., Han, S.H. 2003. Tree-ring Dating of Wood Elements Used for Tongmyungjeon Hall of Changkyung Palace. Journal of Architectural History 12(3): 53-63.

Schweingruber, F.H. 1988. Tree Rings: Basics and Applications of dendrochronology. Kluwer academic publishers, Dordrecht, Holland.

Seo, J.W., Jeong, H.M., Sano, M., Choi, E.B., Park, J.H., Lee, K.H., Kim, Y.J., Park, H.C. 2017. Establishing Tree Ring $\delta 180$ Chronologies for 
Principle Tree Species (T. cuspidata, P. koraiensis, A. koreana, $Q$. mongolica) at Subalpine Zone in Mt. Jiri National Park and Their Correlations with The Corresponding Climate. Journal of the Korean Wood Science and Technology 45(5): 661-670.

Soltani, M., Pourtahmasi, K., Mohammadi, M. 2021. Checking the Originality of Tar Musical Instrument by Using Dendrochronology. Scientific Culture 7(3): 1-12.

Son, B.H., Kim, J.H., Nam, T.K., Lee, K.H., Park, W.K. 2011. Species Identification and Tree-Ring Analysis of Wood Elements in Daesungjeon of Jipyeong Hyanggyo, Yangpyeong, Korea. Journal of the Korean Wood Science and Technology 39(3):
213-220.

Son, B.H., Park, W.K., Yoon, D.H. 2006. Analysis of Species and Tree-Ring Dating of Wood Elements Used for the Daewoongjeon Hall of Youngguksa Temple. Journal of Architectural History 15(2): 23-38.

Speer, J.H. 2010. The Fundamentals of Tree-ring Research. University of Arizona Press, Tucson, USA.

Teskey, R.O., Bongarten, B.C., Cregg, B.M., Dougherty, P.M., Hennessey, T.C. 1987. Physiology and genetics of tree growth response to moisture and temperature stress: An examination of the characteristics of loblolly pine (Pinus taeda L.). Tree Physiology 3(1): 41-61. 


\title{
APPENDIX
}

\author{
(Korean Version)
}

\section{문경 조령 주흘관(제 1관문) 목부재의 수종 및 연륜연대 분석}

초록 : 본 연구에서는 문경 조령 주흘관(제 1관문) 목부재에 대해 수종과 연륜연대분석을 진행하여 재질과 건축역사를 조사하 고자 하였다. 주흘관 목부재(84점)의 수종은 소나무류 76점, 잣나무류 5점, 전나무속 3점으로 확인되었다. 연륜연대분석은 코어링법을 이용하여 시료를 채취하였으며, TSAP프로그램으로 크로스데이팅을 하였다. 연륜연대분석 결과, 소나무류 목부재 59점에 대한 최외각 연도는 1708년 여름-1709년 늦가을, 1792년 여름-1794년 초봄, 1838년 늦가을-1840년 초봄, 1867년과 1872 년 초봄늦가을로 총 4 개의 벌채시기가 확인되었다. 이러한 벌채시기들은 조선왕족실록, 주흘관중수기, 주흘관 성벽 각기의 수리기록과 일치한 것을 확인하였다. 일부 부재들은 수리기록과 벌채시기간의 약 10 년 정도 차이가 나타나 당시 벌채한 목재를 저장하여 사용한 것으로 판단된다.

\section{1. 서론}

나무의 생장은 나무 자신의 유전적, 환경적 요인에 의해 결정되며, 매년 비대·신장생장의 반복으로 연륜을 형성한다(Teskey et al., 1987). 연륜의 요소들 중 연륜폭(tree-ring width)은 측정이 용이하며, 다양한 환경정보가 저장되어 있어 연륜연대학에서 보편적으로 활용된다(Seo et al., 2017). 이러한 연륜폭을 이용하여 연대를 측정하는 방법은 연륜연대측정법이 있으며, 연륜연대 측정법을 적용하기 위해서는 지역별, 수종별로 표준 연륜연대기를 구축할 필요가 있다(Lee et al., 2018). 한국 산림의 주요 수종인 소나무는 한국에서 가장 선호되는 건축 자재이었으며(Park and Lee, 2007), 현재 소나무 표준 연륜패턴이 고려 말까지 작성되어 다수의 목조건축물에 대해 연륜연대측정이 이루어지고 있다(Lee et al., 2021).

국내의 목조건축물에 관한 연륜연대분석은 경복궁 경회루를 시작으로 현재까지 다수의 건물에 적용되었다. 이 중 영동 영국사 대웅전 목부재 55점과 대웅전 하부에서 출토된 탄화건축부재의 절대연대를 확인하여 서로간의 상호관계를 확인한 연구가 있으며(Son et al., 2006), 양평 지평향교 대성전에서는 목부재에 대해 수종 및 연륜연대분석을 진행하여 소나무류 43점, 잣나무 류 6점으로 식별되었고, 연대가 부여된 목부재들의 벌채시기가 1718년과 1720 년으로 과거 기록과 비교하여 수리시기를 확인한 연구가 있다(Son et al., 2011). 또한, 남원 광한루 본루, 익루, 월랑의 목부재와 적심재에 대해 연륜연대분석을 진행하여 본루와 익루 목부재의 벌채시기가 동일한 시기로 중건과 중수시기와 월랑의 증축시기를 역사기록과 비교·확인하였으며(Park et al., 2014), 서울 화계사 대웅전 목부재에 대한 수종과 연륜연대분석을 진행하여 소나무류 26점, 전나무속 1점이 확인되었고, 연대가 부여된 목부재들의 벌채시기가 1869 년과 1870 년으로 확인되어 중건기록 및 종도리 복장물과 일치하는 것을 확인하였다(Lee et al., 2020). 이와 같은 목조건축물은 생물재료이기 때문에 부후 또는 변질되기 쉬우며, 세월이 흐름에 따라 풍해, 충해 등의 피해에 노출된다(Eom and Park, 2018). 따라서 오랜기간 목조건축물을 유지하기 위해서는 수리 및 부재의 교체가 이루어지게 되며, 이에 따라 축성 시기 뿐 만 아니라 수리 및 교체시기를 파악하는 것이 중요하다.

문경 조령 주흘관(제 1 관문)은 사적 제 147 호로 정면 3 칸, 측면 2 칸의 팔작지붕의 문루와 협문(陝門) 2 개가 성곽에 위치하고 있다(Fig. 1). 문경새재의 3 개 관문 중 제1관문(주흘관)이 가장 옛 모습을 지니고 있으며, 1709년(숙종 35)에 축성된 것으로 알려져 있다. 축성 이후, 주흘관중수기」에서는 1752년(영조 28), 1772년(영조 48), 1840년(현종 6)에 수리하였다는 기록과 1721년(경종 1), 1748년(영조 24), 1808년(순조 8), 1880년(고종 17), 1886년(고종 23)에 중수·개축을 하였다고 주흘관 성벽에 각기되어 있다(Mungyeong city, 2020). 다만 이런 기록들은 주흘관에 대한 중수, 수리시기만 기록되어 있고 사용된 목재의 수종과 벌채 및 사용시기 등은 확인할 수 없었다.

따라서 본 연구에서는 문경 조령 주흘관(제 1관문)의 문루와 협문 목부재에 대한 연륜연대분석을 실시하여 중수 및 수리시기 를 확인하고자 하였으며, 연륜연대 대상 부재들에 대한 수종분석을 실시하여 사용된 수종을 확인하고자 하였다.

\section{2. 재료 및 방법}

\section{1. 분석 대상}

주흘관의 문루와 협문 목부재 중 연륜이 50 개 이상인 84 점을 대상으로 수피부에 근접한 부위에서 코어링법으로 시료를 
채취하였다(Table 1, 2). 시료는 특수 제작된 코어형 비트를 전기드릴에 결합하여 코어(직경 $6 \mathrm{~mm}$, 길이 $8 \mathrm{~cm}$ 이내)를 채취하는 코어링법으로 채취하였다. 시료를 채취하여 뚫린 부분은 방부제(Wood keeper-A, Hanchem, Korea)로 방부처리 후, 목재문화재 보수용 수지(주제 - SV 427, 경화제 - HV 427)로 시료를 채취한 공동을 충전하였다. 코어링법은 2000년대 초반부터 현재까지 다수의 건축물에 적용하고 있으며, 시료채취 후 목재문화재 보수용 수지를 이용하여 복원하기 때문에 목부재의 열화나 변형이 문제 된 적은 없다.

\section{2. 분석방법}

\subsection{1. 수종분석}

연륜연대분석을 위해 채취한 코어를 대상으로 면도날을 이용한 핸드섹션방법으로 약 $20 \mu \mathrm{m}$ 두께로 3 단면 박편을 제작하였다. 슬라이드글라스 위에 3 단면을 올려놓고, $50 \%$ 의 글리세린 수용액을 떨어뜨린 뒤 기포가 생기지 않도록 주의해 수종분석용 프레파라트를 제작하였다. 제작된 프레파라트는 광학현미경(Eclipse LV100, Nikon, Japan)으로 조직을 관찰하여 수종을 식별할 수 있는 특징을 찾아 사진을 촬영하였다.

\subsection{2. 연륜연대분석}

채취한 코어를 고정대 위에 부착시키고 사포로 연륜이 선명하게 관찰될 수 있도록 연마하였다. 각 시료의 연륜은 스테레오 현미경(LEICA-S4E, Leica, Germany)과 소프트웨어 TSAP-Win(Rinntech, Germany)에 연결된 연륜폭측정기(LINTAB, Germany)를 이용하여 $0.01 \mathrm{~mm}$ 정확도로 측정하였다. 크로스데이팅은 측정된 시료들의 위(临)연륜과 실(實)연륜을 파악하고, 각 연륜에 정확한 연대를 부여하기 위해 진행하였다(Kim and Park, 2005; Speer, 2010; Soltani et al., 2021). 연륜연대학에서 활용되는 대표적인 크로스데이팅 방법은 연륜연대기간의 상호 적합성을 계산하는 통계적인 방법과 육안으로 확인되는 그래프를 비교하는 방법이 포함된다(Schweingruber, 1988; Norrgård and Helama, 2021). 통계적인 방법은 100 년 이상 기간의 연륜폭 그래프를 상호 비교할 때 t값은 3.5 이상, Glk(gleichläufigkeit)값은 $65 \%$ 이상의 값인 경우 $1 \%$ 수준에서 유의성이 있다고 볼 수 있다(Park et al., 2003). 따라서 연륜분석은 그래프 비교방법(graphic method)과 통계분석을 진행하였으며, 작성된 문경 조령 주흘관 연대기에 절대연도를 부여하기 위하여 한국전통문화대학교에서 소장하고 있는 소나무 표준연대기와 크로스데이팅 을 진행하여 절대연도를 부여하였다.

\section{3. 결과 및 고찰}

\section{1. 수종분석}

문경 조령 주흘관 문루 79점과 협문 5점 등 총 84점의 목부재를 대상으로 수종분석을 진행한 결과, 소나무류 76점, 잣나무류 5점, 전나무속 3점으로 식별되었다. 부재 종류별 수종 식별결과를 Table 3, 4에 요약하였다.

\subsection{1. 소종별 해부학적 특징}

1) 소나무류(Hard pine) - 소나무과(PINACEAE) 소나무속(Pinus spp.)

침엽수재로 조·만재의 이행이 급하며, 박벽의 에피데리얼세포를 가지고 있는 수직수지구가 관찰되었다. 방사조직은 방사유세 포와 방사가도관으로 이루어져 있고, 직교분야벽공은 1 개의 창상형이 주로 관찰되었다. 특히, 소나무속 중 경송류의 주요한 특징이라 할 수 있는 거치상비후가 방사가도관 내에서 관찰되었다. 축방향가도관내의 유연벽공 배열은 1 열로 관찰되었다. 접선단면에서는 수평수지구가 관찰되었고, 방사조직은 단열방사조직과 방추형방사조직이 모두 관찰되었다(Fig. 2). 소나무속에 는 경송류와 연송류가 존재하며, 거치상 비후가 관찰되므로 최종 소나무류로 식별하였다.

\section{2) 잣나무류(Soft pine) - 소나무과(PINACEAE) 소나무속(Pinus spp.)}

침엽수재로 조·만재의 이행이 완만하거나 약간 급하며, 박벽의 에피데리얼세포를 가지고 있는 수직수지구가 관찰되었다. 방사조직은 방사유세포와 방사가도관으로 이루어져 있으며, 직교분야벽공은 1-2개의 창상형으로 주로 2개가 관찰되었다. 소나 무속 중 경송과 달리 거치상비후가 방사가도관 내에서 관찰되지 않았다. 축방향가도관내의 유연벽공 배열은 1 열이 관찰되었다. 접선단면에서는 수평수지구가 관찰되었고 방사조직은 단열방사조직과 방추형방사조직이 모두 관찰되었다(Fig. 3). 소나무속에 는 경송류와 연송류가 존재하며, 거치상 비후가 관찰되지 않으므로 최종 잣나무류로 식별하였다. 
3) 전나무속(Abies spp.) - 소나무과(PINACEAE)

침엽수재로 가도관의 조 - 만재 이행은 완만하고, 횡단면에서 정상수지구는 관찰되지 않았다. 방사조직은 방사유세포로만 구성되어 있었고, 방사유세포의 수평벽에는 단벽공대가 잘 발달되어 있으며, 염주상말단벽으로 이뤄져있었다. 직교분야벽공은 삼나무형으로 2-3개로 관찰되었으며, 축방향가도관의 유연벽공은 1-2열로 배열되어 있었다. 접선단면에서는 수평수지구는 관찰 되지 않았고, 단열방사조직만 관찰되었다(Fig. 4). 우리나라에 분포하는 전나무속에는 전나무, 분비나무, 구상나무 등 3종이 생장하고 있으나, 해부학적으로는 구분이 되지 않아 최종적으로 전나무속으로만 식별하였다.

\section{2. 연륜연대분석}

문경 조령 주흘관 문루와 협문에서 채취한 84점 중 잣나무류로 식별된 5점과 전나무로 식별된 3점을 제외한 소나무류 76점을 대상으로 분석하였다. 76 점 중 54점이 서로 간에 일치하여 연대기 1(Joryeong 1S)이 작성되었다(Fig. 5). 연륜연대기 기간은 157 년으로 절대연도를 부여하기 위해 한국전통문화대학교에서 소장하고 있는 소나무 표준연대기와 크로스데이팅 하였다. 분석 결과, t값 $6.7, \mathrm{G}$ 값 $67 \%$ 로 비교적 높은 통계값과 그래프상으로도 일치하였다(Fig. 6). 따라서 문경 조령관문 주흘관(제1관문) 소나무류 연대기 1(Mungyeong 1S)은 1744년-1869년으로 부여하였다. 연대기에 포함된 부재들 중 수피가 존재하는 일부 내기 둥, 누리개, 상연은 1792 년 여름부터 1794년 초봄 사이에 벌채된 목재가 이용된 것이 확인되었고, 대부분의 부재들은 1838 년 늦가을에서 1840 년 초봄 사이에 벌채된 목재들로 확인되었다. 또한, 마루불명부재 1 과 불명지붕부재 3 부재는 각각 1867 년과 1872 년 초봄에서 가을사이에 벌채된 것으로 확인되었다. 또한 마루장선 및 장선 5점이 서로 일치하여 연대기 2(Joryeong $2 \mathrm{~S}$ )가 작성되었다. 연륜연대기 기간은 113 년으로 소나무 표준연대기와 분석한 결과, t값 $4.7, \mathrm{G}$ 값 $61 \%$ 의 통계값과 그래프상으로 일치하였다. 따라서 문경 조령관문 제1관문(주흘관) 소나무류 연대기 2(Joryeong 2S)는 1596년-1709년으로 부여하였다(Fig. 7). 연대기에 포함된 부재들 중 2점(마루장선 2, 장선 2)은 수피가 존재하였으므로, 1708년 여름부터 1709년 늦가을 사이에 벌채된 것으로 확인되었다.

\section{3. 고찰}

문경 조령 주흘관(제 1관문) 목부재 84점의 수종분석을 진행한 결과, 소나무류 76점, 잣나무류 5점, 전나무속 3점으로 식별되 었다. 소나무류에 속하는 소나무는 한반도의 북부 고원지역을 제외한 우리나라 전지역에서 자생하는 수종으로서 이전 연구에서 조선시대의 목조건축물 목부재에 주로 사용되었으며(Park and Lee, 2007), 이번 연구에서도 동일한 결과를 확인할 수 있었다. 우리나라에 자생하는 잣나무류는 잣나무, 섬잣나무, 눈잣나무 3 종이 존재하며, 섬잣나무는 울릉도에 자생하고, 눈잣나무는 주로 한반도 북부에 자생하여 설악산이 수목한계선이므로 섬잣나무와 눈잣나무가 사용되었을 가능성은 비교적 적어 잣나무일 가능성이 높다(Kong, 2000). 또한 전나무속의 수종은 전나무, 분비나무, 구상나무가 존재하지만, 분비나무와 구상나무는 주로 고산지대에 분포하여 전나무가 사용된 것으로 판단된다(Lee, 1997). 잣나무와 전나무는 소나무에 비해 강도가 낮아 건축부재에 적합하지 않은 수종이다. 따라서 문경 조령 주흘관은 소나무를 주로 이용하여 건축하였으나 소나무가 공급량이 부족한 경우에는 침엽수재인 잣나무와 전나무를 이용하여 충당한 것으로 판단되며, 이전 연구에서 조선시대 궁궐 및 관아 건물에는 대부분 소나무가 사용되었으나, 전나무와 잣나무가 일부 사용되었다는 결과와 일치한다(Park and Lee, 2007).

연륜연대분석 결과, 76 점의 소나무류 부재들 중 59점에 대하여 연대가 부여되었으며, 목부재의 벌채시기가 총 4 개로 확인되었 다. 마루부재인 장선 부재들이 1708년 여름부터 1709년 늦가을사이에 벌채된 것으로 확인되어 초기 축성 부재로 판단되며, 대부분의 부재들은 1838 년 늦가을에서 1840 년 초봄까지 약 1 년 6 개월 사이에 벌채되어 축성 이후 130 년이 지난 이후 대규모 수리가 있었던 것으로 판단된다. 또한, 일부 외기둥, 누리개, 상연들은 1792년 여름부터 1794년 초봄 사이에 벌채되어 대규모 수리 이후 150 년이 지나 일부 부재에 대해 수리 및 교체가 이루어진 것으로 판단된다. 이후 동바리로 추정되는 마루부재와 불명 지붕부재 각각 1 점이 1867 년과 1872 년에 벌채된 것으로 확인되어 1872 년 이후 마루의 부후된 부분에 대해 일부 동바리로 교체하는 비교적 간단한 수리가 지붕수리와 함께 이루어 진 것으로 추정된다(Fig 8).

\section{4. 결론}

문경 조령 주흘관 문루와 협문은 관아 건물로서 소나무를 선택적으로 이용하였고, 일부 부족한 부재에 대해서는 잣나무와 전나무를 이용하여 축조한 것이 확인되었으며, 이전에 연구되었던 조선시대 궁궐 및 관아 건축물들의 수종 구성과 비슷한 결과를 보여주었다(Park, et al., 2018). 또한 연륜연대분석으로 작성된 연대기가 월악산과 속리산 소나무로 만들어진 충청도 표준연대기와 가장 높은 통계값을 보여주고 있어 당시 문경 주변에 자생하는 소나무를 공급하여 수리 및 교체를 진행한 것으로 
판단된다.

연륜연대분석으로 문루 58점과 협문 1점에서 총 4구간의 벌채시기가 확인되었다. 확인된 벌채시기를 문경 조령 주흘관의 축성 및 수리기록(조선왕조실록, 주흘관중수기, 성벽 각기)과 비교하였다(Table 5). 문경 조령 주흘관에 대한 기록 중 「조선왕조 실록- 숙종실록」과「여지도서」에 숙종 34년(1708)에 조령의 축성문제를 논의되어 이듬해인 숙종 35년(1709) 봄부터 축성 역사가 추진되어 축성되었다는 기록이 존재한다(Mungyeong city, 2020). 이는 연륜연대분석을 통해 마루부재인 다수의 장선들 이 비슷한 시기로 확인되어 초기 축성 부재로 판단할 수 있다. 「주흘관중수기」의 기록에서는 헌종 6년(1840)에 중수하였다는 기록이 있으며, 대부분의 부재들이 1838-1840년 사이에 벌채된 것이 확인되어 1840년에 중수 또는 대규모 수리가 진행된 것으로 판단된다(Mungyeong city, 2020). 또한 성벽의 각기에서 1808 년에 수리가 이루어 졌다는 기록이 있으며, 연륜연대분석 에도 1792-1794년 사이에 벌채된 기둥과 도리가 확인되어 약 10년 전에 미리 벌채한 목재를 이용하여 1808 년에 비교적 큰 수리가 이루어진 것으로 판단되고, 1867년과 1872년에 각각 벌채된 동바리 마루부재와 지붕부재는 1880 년과 1886년에 수리가 되었다는 성벽 각기 기록을 보아 미리 벌채된 목재를 이용하여 간단한 수리 및 보수가 이루어진 것으로 판단된다.

문경 조령 주흘관은 서적과 성벽의 각기를 통해 다양한 수리기록들이 확인되었으며, 연륜연대분석 결과와 일치하여 연륜연대 분석의 정확성을 다시 확인할 수 있었다. 또한 일부 부재들은 수리기록과 벌채시기의 차이가 약 10 년 정도 차이를 보여주어 당시 목재를 벌채하여 저장했던 것으로 추정되며, 이후 조선시대 건축물에 대한 연륜연대분석을 지속적으로 이루어진다면 조선시대의 건축물에 사용되는 목재의 저장 및 이용방법에 대해 보다 정확히 알 수 있을 것으로 판단된다. 